\title{
Efek Diet Tinggi Fruktosa terhadap Profil Lipid Tikus Rattus Rattus norvegicus Strain Wistar
}

\author{
Nurlaili Susanti ${ }^{1}$, Ermin Rahmawati ${ }^{2}$, Risma Aprinda K. ${ }^{3}$ \\ Fakultas Kedokteran dan Ilmu Kesehatan, UIN Maulana Malik Ibrahim Malang \\ Email: $\underline{\text { dr.santie@gmail.com }}{ }^{1}$, ermin_najwa@gmail.com ${ }^{2}$, risma.aprinda@yahoo.com $^{3}$
}

\begin{abstract}
Abstrak
Sejak beribu tahun yang lalu, orang mengonsumsi fruktosa dalam jumlah terbatas dari buahbuahan segar dan sayuran. Fruktosa yang terdapat dalam bahan alami ini tidak membahayakan kesehatan. Akan tetapi saat ini, fruktosa banyak digunakan sebagai pemanis oleh industri makanan dan minuman dalam bentuk high fructose corn syrup (HFCS). Fruktosa sangat efisien menginduksi lipogenesis. Penelitian ini dilakukan untuk membuktikan pengaruh konsumsi fruktosa terhadap profil lipid pada hewan coba. Penelitian ini merupakan penelitian eksperimental laboratoris dengan desain postest only controle group. Sampel dibagi dalam 4 kelompok perlakuan dengan masing-masing 6 ekor tikus terdiri dari tikus diet normal (K), tikus diet fruktosa $10 \%$ (P1), tikus diet fruktosa 30\% (P2), dan tikus diet fruktosa 60\% (P3). Fruktosa diberikan secara peroral dengan menggunakan sonde selama 8 minggu. Pada akhir penelitian, dilakukan pengambilan sampel darah untuk pengukuran profil lipid dengan spektrofotometer. Hasil penelitian pada tikus yang diberikan diet fruktosa menunjukkan kadar kolesterol total, LDL, dan trigliserida yang signifikan lebih tinggi dibandingkan kontrol, sedangkan kadar HDL lebih rendah dibandingkan kontrol. Dapat disimpulkan bahwa diet tinggi fruktosa dapat menginduksi terjadinya dislipidemia.
\end{abstract}

Kata Kunci: fruktosa, profil lipid.

\begin{abstract}
Since thousands of years ago, people consumed limited amounts of fructose from fresh fruits and vegetables. Fructose contained in these natural ingredients does not harmful to health. However, at present, fructose is widely used as a sweetener by the food and beverage industry in the form of high fructose corn syrup (HFCS). Fructose induces lipogenesis very efficient. This study was conducted to prove the effect of fructose consumption on lipid profiles in experimental animals. This research is a laboratory experimental study with posttest design only controle group. The samples were divided into 4 treatment groups with 6 rats each consisting of normal diet $(\mathrm{K})$, $10 \%$ fructose diet $(\mathrm{P} 1), 30 \%$ fructose diet $(\mathrm{P} 2)$, and $60 \%$ fructose $(\mathrm{P} 3)$ diet. Fructose is given orally by using a sonde for 8 weeks. At the end of the study, blood samples were taken to measure lipid profiles with a spectrophotometer. The results of the study on rats given a fructose diet showed that total cholesterol, LDL and triglyceride levels were significantly higher than controls, while HDL levels were lower than controls. It can be concluded that a high fructose diet can induce dyslipidemia.
\end{abstract}

Keyword: fructose, lipid profile. 


\section{PENDAHULUAN}

Saat ini penyakit kardiometabolik utamanya penyakit jantung koroner dan diabetes mellitus tipe 2 menjadi soroton setiap Negara dikarenakan prevalensinya yang tinggi dengan kecenderungan meningkat pertahunnya dan angka kematian yang tinggi. Kejadian penyakit kardiometabolik menjadi beban ekonomi di setiap negara di dunia dikarenakan tingginya biaya perawatan penderita diabetes, yang disebabkan ketidakmampuan penderita melakukan aktivitas hariannya dan juga tingginya angka komplikasi makro dan mikrovaskuler dari diabetes mellitus tipe 2 sehingga digolongkan masyarakat yang tidak produktif. Prevalensi diabetes mellitus tipe 2 di Amerika pada tahun 2015 tercatat mencapai 30,3 juta, atau 9,4\% dari populasi penduduk. Dari 30,3 juta orang dewasa dengan diabetes, 23,1 juta yang berhasil didiagnosis, sementara 7,2 juta masih tidak terdiagnosis. American Diabetes Association juga melaporkan bahwa 84,1 juta orang Amerika berusia 18 dan lebih tua memiliki pradiabetes. Diabetes tetap menjadi penyebab kematian ke 7 di Amerika Serikat pada tahun 2015, dengan 79.535 sertifikat kematian mencantumkannya sebagai penyebab kematian, dan total 252.806 sertifikat kematian yang mencantumkan diabetes sebagai penyebab kematian yang mendasari atau berkontribusi.

Pada tahun 2013, jumlah penderita diabetes di Eropa diperkirakan mencapai 56 juta penduduk dengan perkiraan keseluruhan prevalensi 8,5\% dengan variasi di 56 negara yang beragam dari 2,4\% di Moldova sampai 14,9\% di Turki.. Untuk tahun 2035, diperkirakan terjadi peningkatan lebih lanjut sejumlah hampir 10 juta penderita diabetes mellitus tipe 2 di Europa. Di Timur Tengah dah Afrika selatan estimasi prevalensi diabetes mellitus tipe 2 diperkirakan pada kisaran 9,2\% dengan jumlah populasi 34 juta penderita, dimana 17 jutanya belum terdiagnosis. Prevalensi diabetes di Australia adalah $8,0 \%$ pada pria dan $6,8 \%$ pada wanita, dengan tambahan data $17,4 \%$ pria dan $15,4 \%$ wanita dinyatakan mengalami toleransi glukosa tertanggu. Bahkan di kelompok usia termuda sekalipun di Australia (25-34 tahun), 5,7\% subyek memiliki toleransi glukosa abnormal. prevalensi diabetes di China telah meningkat secara dramatis, dari sekitar $1 \%$ pada tahun 1980 menjadi 9,7\% dalam perkiraan terbaru dari survei nasional yang diselenggarakan pada tahun 2015. Peningkatan ini dihipotesiskan karena bertambahnya usia, urbanisasi, riwayat keluarga yang positif, obesitas, dan hipertensi. Sebuah tinjauan dari Survei Kesehatan dan Gizi Nasional Korea (KNHANES) menunjukkan bahwa 
prevalensi diabetes pada orang Korea meningkat dari 0,91\% pada tahun 1971 menjadi 9,9\% pada tahun 2009. Selain itu, terjadi peningkatan prevalensi prediabetes di Negaranegara. Faktor-faktor tersebut membuat Diabetes Atlas memprediksikan bahwa penduduk Negara Asia dan Afirika akan memiliki proporsi penderita diabetes tertinggi di tahun 2030. Berdasarkan data dari Riset Kesehatan Dasar yang dilakukan oleh Kementerian Kesehatan Republik Indonesia, disimpulkan bahwa proporsi diabetes mellitus mengalami peningkatan hamper dua kali lipat di tahun 2013 bila dibandingkan dengan tahun 2007. Estimasi jumlah penderita diabetes Mellitus di Indonesia tahun 2013 mencapai total 12 juta penduduk dengan proporsi sebesar 6,9\%, penduduk yang mengalami toleransi glukosa terganggu TGT) diperkirakan sebesar 52 juta penduduk atau proporsi sebesar $29,9 \%$ dan penduduk yang mengalami glukosa darah puasa terganggu (GDT) sekitar 64 juta penduduk dengan jumlah proporsi sebesar 36,6\%.

Kementerian kesehatan Indonesia menetapkan dua kriteria faktor resiko diabetes mellitus yaitu (1) faktor resiko yang tidak dapat dimodifikasi dan (2) faktor resiko yang dapat dimodifikasi. Faktor risiko yang tidak dapat dimodifikasi diantaranya adalah ras, etnik, umur, jenis kelamin, riwayat keluarga dengan diabetes mellitus, riwayat melahirkan bayi dengan berat badan lebih dari 4000 gram dan riwayat lahir dengan berat badan lahir rendah (kurang dari 2500 gram). Sedangkan factor risiko yang dapat dimodifikasi yaitu berat badan lebih, obesitas sentral, kurangnya aktivitas fisik, hipertensi, dyslipidemia, diet tidak sehat/ tidak seimbang, merokok, riwayat TGT atay GDT.

Globalisasi, urbanisasi, kemajuan dunia teknologi menyebabkan peralihan pola konsumsi populasi penduduk manusia menjadi tinggi kalori, dimana sumber energi tersebut salah satunya didapat dari gula dan pemanis buatan. Konsumsi gula menunjukkan tren meningkat di seluruh dunia termasuk negara berkembang utamanya Asia dan India. Amanda dalam penelitiannya melaporkan bahwa di Brazil terjadi peningkatan konsumsi gula dari sumber nasi, tepung, kopi, jus buah dan minuman ringan (Souza AM, 2013). Hasil serupa dari sebuah data survey nasional di Amerika Serikat menunjukkan adanya peningkatan asupan energi dari makanan minuman berkalori tinggi dengan pemanis sebesar 3,9 kalori pada tahun 1977 menjadi 9,2\% di tahun 2001. Hasil studi lain menyebutkan bahwa prevalensi konsumsi minuman ringan di antara pemuda usia 6 hingga 17 tahun meningkat 48\%, dari 37\% di 1977/1978 menjadi 56\% di 1994/1998 (French SA, 2003). 
Sejak beribu tahun yang lalu, orang mengonsumsi fruktosa dalam jumlah terbatas dari buah-buahan segar dan sayuran. Fruktosa yang terdapat dalam bahan alami ini tidak membahayakan kesehatan. Akan tetapi saat ini, fruktosa banyak digunakan sebagai pemanis oleh industri makanan dan minuman seperti minuman ringan, kukis, jeli, dan es krim dalam bentuk high fructose corn syrup (HFCS) karena mempunyai rasa paling manis diantara jenis karbohidrat lain dan harga yang relatif murah (Johnson et.al., 2009; Basciano et.al., 2005; Bantle, 2008).

Fruktosa sangat efisien menginduksi lipogenesis. Pemberian fruktosa dapat meningkatkan ekspresi gen lipogenik seperti fatty acid sintase (FAS), acetyl-CoA carboxylase (ACC), dan stearoyl-CoA desaturase (SCD). Sel hepar tikus yang diberi fruktosa menunjukan penurunan ekspresi PPAR $\alpha$ yang menyebabkan oksidasi lipid menurun dan meningkatnya akumulasi lipid (Basciano et.al., 2005; Swarbrick et.al., 2008). Konsumsi fruktosa lebih dari $25 \%$ kebutuhan energi per hari (sekitar $85 \mathrm{~g}$ fruktosa) dapat menyebabkan hipertrigliseridemia dan resistensi insulin (Johnson et.al., 2009).

Islam telah mengajarkan untuk mengkonsumsi makanan dan minuman yang halal dan thoyyib. Thoyyib bermakna mengandung nutrisi yang dibutuhkan oleh tubuh dan dikonsumsi dalam jumlah sesuai kebutuhan tubuh seseorang. Oleh karena itu, Islam dengan tegas melarang berlebih-lebihan (isrof) dalam makan dan minum karena dapat berdampak buruk bagi kesehatan. Sebagaimana firman Allah dalam Surat Al-A'raf ayat 31 berikut:

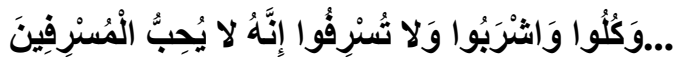

Artinya : ... Makan dan minumlah, dan janganlah berlebihan. Sesungguhnya Allah tidak menyukai orang-orang yang berlebih-lebihan.

Penelitian ini menguji pengaruh pemberian diet tinggi fruktosa pada tikus Rattus norvegicus strain wistar terhadap profil lipid yaitu kadar kolesterol total, kadar Low Density Lipoprotein ( $L D L)$, kadar High Density Lipoprotein (HDL), dan kadar Trigliserida. Fruktosa diberikan dalam beberapa dosis untuk menilai batas aman dosis konsumsi fruktosa sehari-hari, sehingga dapat terhindar dari isrof yang membahayakan kesehatan. 


\section{METODE PENELITIAN}

Penelitian ini merupakan penelitian eksperimental laboratoris dengan desain post test only control group. Sampel yang digunakan dalam penelitian ini adalah tikus Rattus norvegicus strain Wistar sebanyak 24 ekor, jenis kelamin jantan, usia $\pm 4-8$ minggu, warna bulu putih dan tikus aktif. Sampel penelitian dibagi dalam 4 kelompok secara random, yaitu:

a. K (kontrol) adalah kelompok yang tidak diberi perlakuan fruktosa oral.

b. P1 (perlakuan 1) adalah kelompok yang diberi fruktosa oral sebanyak $10 \%$.

c. P2 (perlakuan 2) adalah kelompok yang diberi fruktosa oral sebanyak $30 \%$.

d. P3 (perlakuan 3) adalah kelompok yang diberi fruktosa oral sebanyak $60 \%$.

Fruktosa oral diberikan dengan cara disonde kepada hewan coba selama 8 minggu. Selama penelitian, hewan coba diperlakukan sebaik-baiknya, diusahakan agar bebas stres, leluasa bergerak dan diberikan makanan dan minuman setiap hari secara ad libitum. Kandang ditempatkan di ruangan yang tenang, cukup cahaya, diatur suhu dan kelembapan yang sesuai. Kandang dijaga kebersihannya dan sekam diganti tiga hari sekali.

Pada akhir penelitian, tikus dikorbankan dengan cara inhalasi kloroform, kemudian dilakukan pengambilan sampel darah dari jantung. Sampel darah digunakan untuk uji profil lipid meliputi kadar kolesterol total, LDL, HDL, dan trigliserida dengan spektrofotometer. Data yang didapat dianalisis dengan software SPSS v.20 dengan menggunakan uji One Way Anova untuk melihat perbedaan antara kelompok dan dilanjutkan dengan uji Post Hoc Tuckey untuk mengetahui letak perbedaannya. Uji statistik dilakukan pada derajat kepercayaan $\mathrm{p}<0,05$.

\section{HASIL PENELITIAN}

Berdasarkan hasil penelitian, diperoleh data perkembangan berat badan pada awal dan akhir penelitian serta kadar kolesterol total, LDL, HDL, dan trigliserida pada akhir penelitian sebagai berikut: 


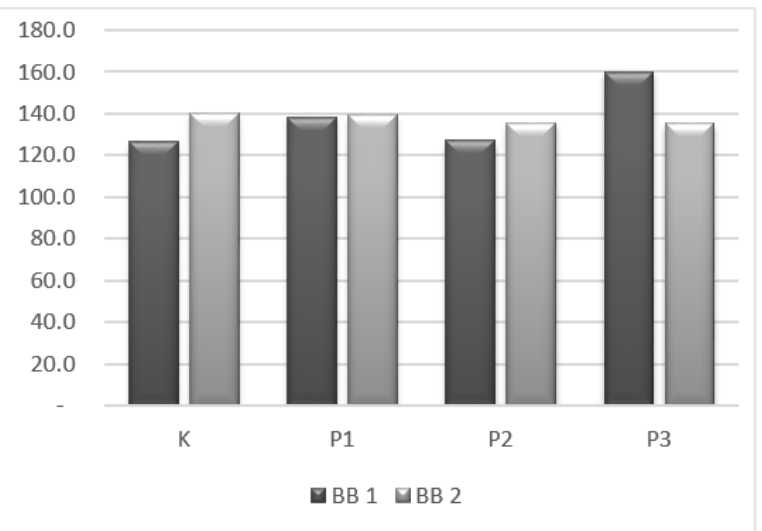

Gambar 1. Diagram Perkembangan Berat Badan Awal dan Akhir Penelitian

Kelompok perlakuan $\mathrm{K}=$ Tikus Normal, $\mathrm{P} 1=$ fruktosa oral $10 \%, \mathrm{P} 2=$ fruktosa oral $30 \%, \mathrm{P} 3=$ fruktosa oral 60\%, BB 1: Berat Badan Awal Penelitian, BB 2: Berat Badan Akhir Penelitian.

Gambar 1. menunjukkan bahwa terjadi peningkatan rata-rata berat badan pada awal penelitian (BB 1) dengan berat badan pada akhir penelitian (BB 2). Data terdistibusi normal $(\mathrm{p}=0,972)$ dan homogen $(\mathrm{p}=0,454)$. Uji One way ANOVA diketahui bahwa tidak ada perbedaan yang signifikan dengan nilai $\mathrm{p}=0,100$.

Tabel 1. Profil Lipid pada Akhir Penelitian (mg/dl)

\begin{tabular}{ccccc}
\hline $\begin{array}{c}\text { Kelompok } \\
\text { Perlakuan }\end{array}$ & $\begin{array}{c}\text { Kolesterol } \\
\text { Total }\end{array}$ & LDL & HDL & Trigliserida \\
\hline K & $151 \pm 28.95$ & $72 \pm 20.22$ & $60 \pm 31.69$ & $96 \pm 40.97$ \\
P1 & $246 \pm 22.16$ & $142 \pm 29.95$ & $51 \pm 24.89$ & $266 \pm 41.24$ \\
P2 & $285 \pm 26.36$ & $187 \pm 26.59$ & $44 \pm 21.09$ & $265 \pm 52.66$ \\
P3 & $414 \pm 73.49$ & $324 \pm 72.15$ & $35 \pm 9.31$ & $275 \pm 51.09$ \\
\hline
\end{tabular}

Tabel 2. Hasil Uji One way ANOVA dan Bonferroni Profil Lipid

\begin{tabular}{ccc}
\hline Parameter & $\mathbf{p}$ & \multicolumn{1}{c}{ Bonferroni } \\
\hline Kolesterol Total & 0,000 & K dengan P1, P2 dan P3 \\
LDL & 0,000 & K dengan P2 dan P3 \\
HDL & 0,338 & \\
Trigliserida & 0,000 & K dengan P1, P2 dan P3 \\
\hline
\end{tabular}




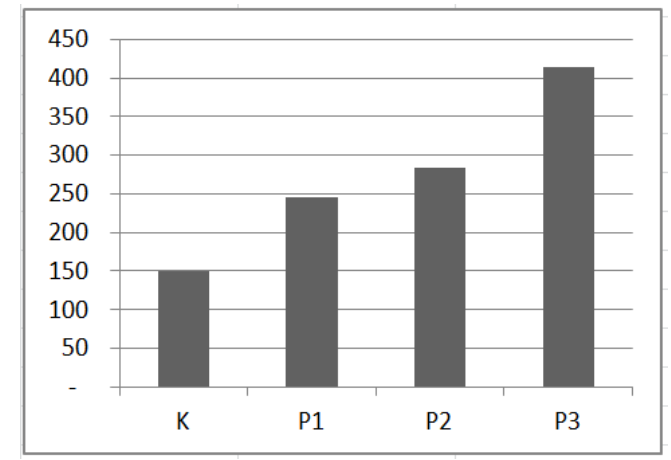

(A)

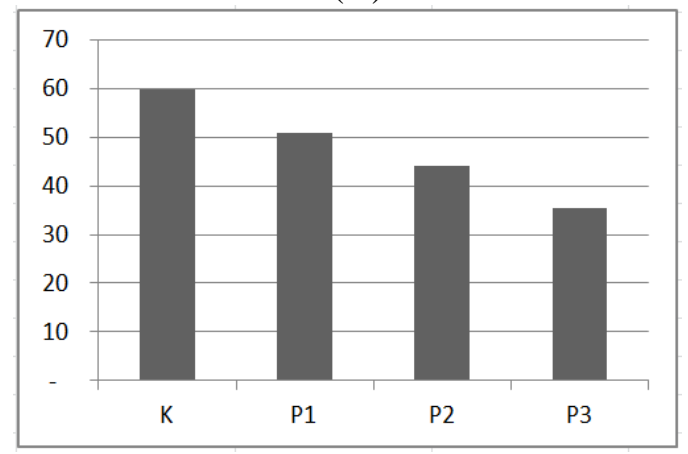

(C)

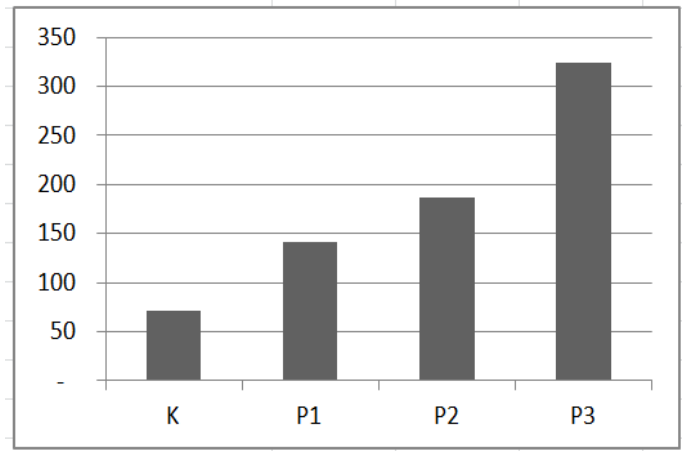

(B)

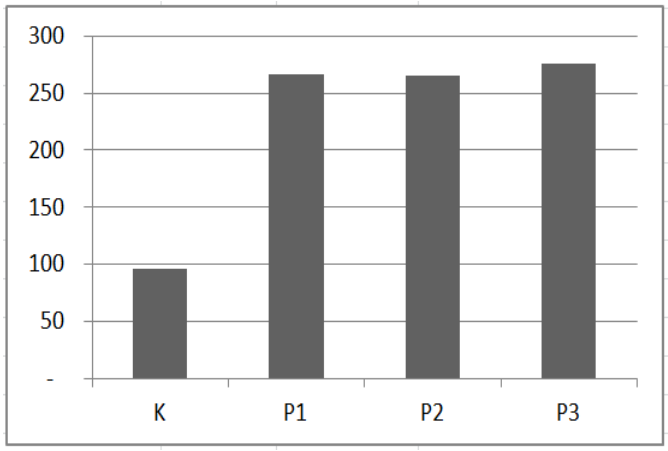

(D)

Gambar 2. Diagram Profil Lipid pada Akhir Penelitian, (A) Kadar Kolesterol Total, (B) Kadar LDL, (C) Kadar HDL, (D) Kadar Trigliserida

Kelompok perlakuan $\mathrm{K}=$ Tikus Normal, $\mathrm{P} 1$ = fruktosa oral 10\%, P2 = fruktosa oral 30\%, P3 = fruktosa oral $60 \%$.

Tabel 1 dan Gambar 2 menunjukkan bahwa kelompok perlakuan memiliki ratarata kadar kolesterol total, kadar LDL dan kadar trigliserida pada akhir penelitian lebih tinggi dibandingkan kelompok kontrol, sedangkan rata-rata kadar HDL lebih rendah dibandingkan kelompok kontrol. Hasil analisis statistik pada data kadar kolesterol total, kadar LDL dan kadar trigliserida menunjukkan perbedaan yang signifikan dengan nilai $\mathrm{p}<0,000$ sedangkan data kadar HDL tidak signifikan secara statistik.

\section{PEMBAHASAN}

Fruktosa merupakan gula sederhana yang memberikan rasa manis, terdapat pada makanan alami seperti buah-buahan, madu, sayuran, dan biji-bijian. Fruktosa mempunyai rasa lebih manis daripada glukosa dan sukrosa. Fruktosa digunakan sebagai pemanis oleh industri makanan dan minuman seperti soft drink, pastries, cookies, gums, jelly, dessert dalam bentuk High Fructose Corn Syrup (HFCS) (Johnson et.al., 2009; Basciano et.al., 2005; Bantle, 2008). 
Penimbangan berat badan pada awal dan akhir perlakuan dilakukan untuk mengetahui perbedaan berat badan sebelum dan setelah perlakuan pemberian diet fruktosa. Hasil penelitian menunjukkan bahwa diet fruktosa dalam berbagai dosis tidak berpengaruh signifikan pada kenaikan berat badan. Pengaruh fruktosa pada kenaikan berat badan telah dilaporkan dalam beberapa penelitian terdahulu. Fruktosa menyebabkan peningkatan asupan kalori dan penambahan berat badan karena tidak memicu produksi insulin dan leptin sehingga tidak menginduksi rasa kenyang. Penelitian pada manusia yang mendapat diet fruktosa $28 \%$ kalori selama 10 minggu didapatkan peningkatan berat badan.

Penelitian lain menyatakan bahwa diet fruktosa tidak menyebabkan peningkatan berat badan. Diet fruktosa 1,5 gram/ hari pada individu sehat selama 4 minggu dapat meningkatkan kadar glukosa dan trigliserida plasma tanpa kenaikan berat badan yang signifikan. Penelitian DeBosch et al. (2013) menyatakan bahwa diet tinggi fruktosa dapat memicu peningkatan adipogenesis di organ viseral dan menurunkan sensitivitas insulin tanpa meningkatkan berat badan.

Penelitian ini bertujuan untuk menguji pengaruh pemberian diet tinggi fruktosa pada tikus Rattus norvegicus strain wistar terhadap profil lipid yaitu kadar kolesterol total, kadar Low Density Lipoprotein (LDL), kadar High Density Lipoprotein (HDL), dan kadar Trigliserida. Hasil penelitian ini menunjukkan bahwa diet tinggi fruktosa dapat meningkatkan kadar kolesterol total, LDL dan trigliserida secara signifikan pada tikus. Sedangkan penurunan kadar HDL setelah pemberian diet tinggi fruktosa tidak signifikan secara statistik. Peningkatan kadar kolesterol total, LDL dan trigliserida serta penurunan kadar HDL sudah terjadi pada pemberian diet tinggi fruktosa dengan konsentrasi $10 \%$ selama 8 minggu.

Fruktosa yang masuk ke saluran cerna mengalami absorbsi dari lumen ke membran apikal epitel intestinal diperantarai oleh Glucose Transporter 5 (GLUT-5). Transpor ini terjadi secara pasif searah gradien konsentrasi dari tinggi ke rendah dan tidak memerlukan ion $\mathrm{Na}+$ sebagai kotranspor. Sedangkan absorbsi fruktosa dari membran epitel intestinal masuk ke cairan ekstraseluler diperantarai oleh GLUT-2. Transpor terjadi dari konsentrasi rendah ke tinggi melalui pompa $\mathrm{Na}+\mathrm{K}+$ yang membutuhkan ATP. Absorpsi fruktosa lebih lambat dibandingkan glukosa karena melawan gradien konsentrasi, akan tetapi berhubung glukosa dan fruktosa ditranspor melalui GLUT2, maka dengan tersedianya 
energi tersebut, absorpsi glukosa akan membawa serta fruktosa (Crouzoulon dan Korieh, 1991).

Fruktosa tidak membutuhkan insulin untuk masuk ke dalam sel dan hanya sebagian kecil fruktosa yang terlibat dalam metabolisme glukosa. Akan tetapi pada kondisi sel mengalami starvasi, gluconeogenesis akan meningkat (Bantle, 2008). Konsumsi fruktosa juga tidak menstimulasi produksi insulin. Konsentrasi insulin yang rendah setelah konsumsi fruktosa dihubungkan dengan rendahnya kadar leptin (Zhang D.M. et al, 2017).

Fruktosa yang diabsorbsi di saluran cerna kemudian dikirim ke liver melalui vena porta. Fruktosa difosforilasi oleh ATP menjadi fruktosa-1 fosfat dengan bantuan enzim fruktokinase, kemudian dipecah oleh aldolase B menjadi gliseraldehid dan dihidroksiaseton fosfat. Keduanya dapat dirubah menjadi gliseraldehid 3 fosfat. Sehingga fruktosa dimetabolisme menjadi menjadi 2 triose fosfat yang melewati tahapan glikolisis. Produk metabolisme fruktosa pada jalur glikolisis di liver adalah glukosa, glikogen, laktat, dan piruvat (Elliot et al., 2002).

Berbeda dengan glukosa, metabolisme fruktosa di hepar tidak dihambat pada level fosfofruktokinase. Konsentrasi fruktosa yang tinggi menyebabkan peningkatan produksi laktat dan asetil CoA. Sehingga fruktosa bersifat lebih lipogenik dari pada glukosa. Fruktosa juga tidak mampu merangsang sekresi insulin akibat sedikitnya fruktosa transporter (GLUT-5) di sel ß pankreas. Kondisi ini dihubungkan dengan konsumsi kronis fruktosa dalam dosis tinggi yang dapat menyebabkan gangguan jangka panjang pada regulasi energi dan adipogenesis tubuh (Elliot et al., 2002).

\section{KESIMPULAN}

Pemberian diet tinggi fruktosa dapat meningkatkan kadar kolesterol total, kolesterol Low Density Lipoprotein (LDL), dan Trigliserida serta menurunkan kadar kolesterol High Density Lipoprotein (HDL).

\section{DAFTAR PUSTAKA}

Basciano H, Federico L and Adeli K. Fructose, insulin resistance, and metabolic dyslipidemia. Nutr \& Metab. 2005; 2(5).

Bantle JP. Dietary fructose and metabolic syndrome and diabetes. J Nutr. 2008; 1263S$67 \mathrm{~S}$. 
Crouzoulon G \& Korieh A. Fructose transport by Rat intestinal brush border membrane vesicles. Effect of high fructose diet followed by return to standart diet. Compe Biochem and Physiol Part A. 1991; 1:175-82.

DeBosch, B., Chen, Z., Finck, B.N., Chi, M., Moley, K.H. 2013. Glucose transporter-8 (GLUT-8) mediates glucose intolerance and dyslipidemia in high-fuctose diet-fed male mice. Mol Endocrinol. 27 (11): 1887-1896.

Elliot, S., Keim, N., Stern, J., Teff, K., Havel, P. 2002. Fructose, weight gain, and the insulin resistance syndrome. Am J Clin Nutr 76 : 911-912.

French SA, Lin B, Guthrie JF. 2003.National trends in soft drink consumption among children and adolescents age 6 to 17 years : Prevalence, amounts and sources 1977/1978 to 1994/1998.J Am Diet Assoc 103:1326-1331.

Johnson RJ, Perez-Posa SE, Sautin YY, Manitius J, Lozada LG, Feig DI, et al. Hypothesis: Could excessive fructose intake and uric acid cause type 2 diabetes? Endocr Rev. 2009; 30(1).

Souza AM, Pereira RA, Yokoo EM, Levy RB, Sichieri R.2013.Most consumed foods in Brazil:National Dietary Survey 2008-2009.Rev Saude Publica 47.

Swarbrick MM, Stanhope K, Elliott SS, Graham JL, Krauss RM, Christiansen MP, et al. 2008. Consumption of fructose sweetened beverages for 10 weeks increase postprandial triacylglycerol and apolipoprotein-B concentrations in overweight and obese women. Br J Nutr. 100.

Zhang D-M, Jiao R-Q, dan Kong L-D. 2017. High Dietary Fructose: Direct or Indirect Dangerous Factors Distributing Tissue and Organ Function, Nutrien 9 (335). 